\title{
Klinisk epidemiologi
}

Dette temanummeret av Norsk Epidemiologi er viet klinisk epidemiologi. Men "klinisk epidemiologi", hva er det? I Modern Epidemiology gir Kenneth Rothman denne tentative definisjonen: "...the study of illness outcomes in persons seen by providers of health care.", men erkjenner samtidig at "The overall strategy used in clinical epidemiology is exactly that used in other areas of epidemiology...”. Når man tar i betraktning at det selv innen tradisjonell epidemiologi, der det ikke er naturlig å snakke om klinikk eller pasienter, vil være undergrupper med diagnoser eller behov for behandling, blir avgrensningen mot klinisk epidemiologi mer uklar. De fleste aspekter ved sykdom vil således kunne falle inn under begrepet "klinisk epidemiologi", inkludert risikofaktorer, forebyggende tiltak, diagnostikk, prognose og behandling.

Denne brede tolkningen av begrepet gjenspeiler seg i den responsen vi fikk ved henvendelse til forskningsmiljøene da vi startet arbeidet med dette temanummeret. Artiklene spenner over et bredt spektrum av temaer og metoder og viser bredden i norsk klinisk epidemiologi. Eriksen og Evensens undersøkelse av forskningens betingelser ved et universitetssykehus gir et godt bilde av rammevilkårene for den kliniske epidemiologien i Norge i dag. Farup gir en god oversikt over metodologiske tilnærminger til et klinisk datamateriale, og Abdelnoor og Sandven setter søkelyset på det viktige skillet mellom forklarende og pragmatisk strategi ved klinisk forskning.

De unike norske mulighetene for befolkningsstu- dier er også representert i dette nummeret. Ursin og medarbeidere presenterer en studie om søvn basert på datamaterialet i Hordalandsundersøkelsen - HUSK. Gjertsen og medarbeidere presenterer det nylig startede nasjonale registeret for hoftebrudd. Studien "Barn i Bergen", som er en screening av alle elever fra andre til fjerde klasse i Bergen med nesten 10000 inkluderte barn, presenteres av Posserud med spesiell vinkling mot autisme. Tromsøundersøkelsene er representert ved Jordes studie av parathyroideahormon og blodtrykk.

De siste fire artiklene i dette nummeret omhandler en av de viktigste årsakene til kostnadskrevende sykemelding og tidlig uførhet, nemlig muskel-skjelettplager. Alvær og medarbeidere beskriver en interessant studie av bentetthet og vitamin D. Videre bidrar Ihlebæk og medarbeidere med en studie av subjektive helseplager hos personer med whiplash-skader, som viser at komorbiditet er et viktig aspekt ved denne tilstanden. Måleproblematikk ved kroniske muskel-skjelettplager diskuteres av Skouen og Kvåle, mens Hagen og medarbeidere presenterer et mulig behandlingsopplegg for personer med ryggplager.

Vi håper dette nummeret av Norsk Epidemiologi gir en velporsjonert, god og delikat demonstrasjon av hva som rører seg i norsk klinisk epidemiologi for tiden. Dessuten har vi et ønske om at det kan bidra til å øke interessen, rammene og mulighetene for god og uavhengig klinisk epidemiologisk forskning. God lesning!

\section{Gjesteredaktører}

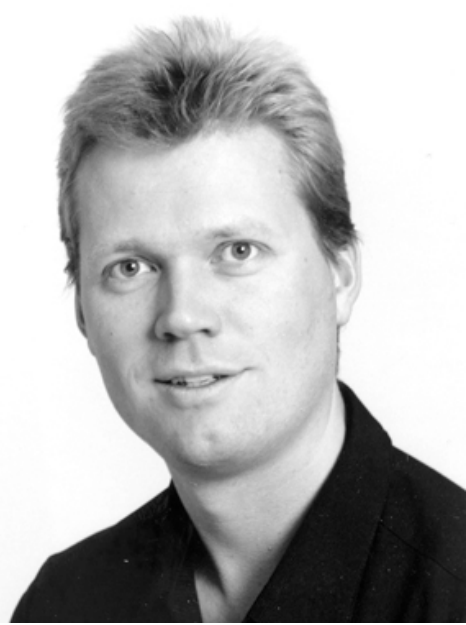

Stein Atle Lie

Unifob helse, Universitetsforskning i Bergen stein.lie@unifob.uib.no

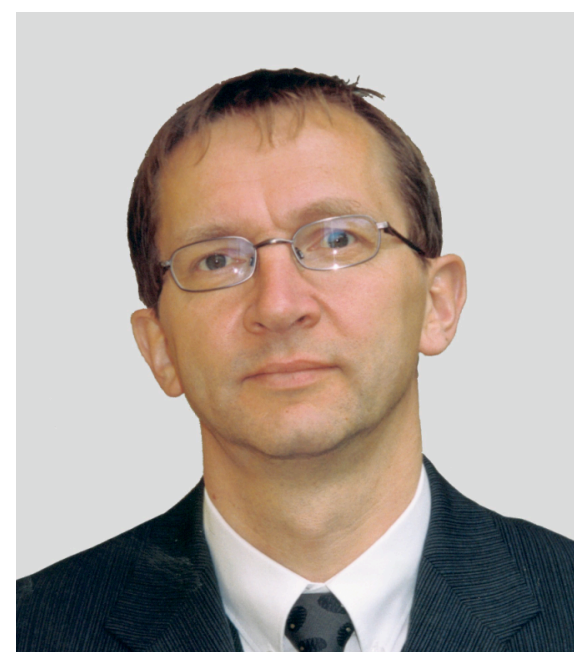

Bjørn Odvar Eriksen

Klinisk forskningssenter, Universitetsssykehuset Nord-Norge, Tromsø bjorn.odvar.eriksen@unn.no 